\title{
GAMBARAN PERILAKU DAN CARA MERAWAT GIGI TIRUAN SEBAGIAN LEPASAN PADA LANSIA DI PANTI WERDA MINAHASA INDUK
}

\author{
${ }^{1}$ Pingkan E.O. Lengkong \\ ${ }^{2}$ Damajanti H. C. Pangemanan \\ ${ }^{3}$ Ni Wayan Mariati
}

\author{
${ }^{1}$ Kandidat Skripsi Program Studi Pendidikan Dokter Gigi Fakultas Kedokteran \\ ${ }^{2}$ Bagian Fisiologi Fakultas Kedokteran \\ ${ }^{3}$ Program Studi Pendidikan Dokter Gigi Fakultas Kedokteran \\ Universitas Sam Ratulangi Manado \\ E-mail: pingkan.lengkong@gmail.com
}

\begin{abstract}
Removable partial dentures (RPDs) is a denture that replaces one or more missing teeth in the maxilla or mandible and can be removed by the patient. Patients maintain hygiene habits removable partial dentures can be seen from the frequency, time, and method used to clean dentures varies between individuals and different communities. The purpose of this study is to describe the behavior and how to care RPDs for the elderly in Panti Werda Minahasa.This type of research is a descriptive study with cross sectional study. The samples were all elderly who meet the inclusion criteria were age 60-80 years using RPDs in seven nursing homes in Minahasa. Based on the research that has been conducted, most respondents RPDs cleaning by brushing without toothpaste $1(3.3 \%)$ and brushing with toothpaste totaled 29 respondents $(96.67 \%)$. A total of 13 respondents (43.3\%) did immersion RPDs. Most respondents simply did immersion by using water that are 17 respondents $(56.67 \%)$, and no one do immersion using a chemical solution. Most respondents, 13 respondents (43.3\%) RPDs cleaning once a day, as many as 28 respondents $(93.33 \%)$ did not find any difficulty in cleaning RPDs, all respondents (100\%) did not get instruction after assembling, as many as 22 respondents (73.3\%) using RPDs at night while sleeping.Conclusion: Based on behavior, most respondents used RPDs at night while sleeping. Based on how to brush, most respondents clean their RPDs by brushing with toothbrushes and toothpaste. Based on how to care for the soaking, most respondents did soaking with water.
\end{abstract}

Keywords: removable partial dentures, elderly

Abstrak: Gigi tiruan sebagian lepasan (GTSL) adalah gigi tiruan yang menggantikan satu atau beberapa gigi yang hilang pada rahang atas atau rahang bawah dan dapat dilepas oleh pasien. Kebiasaan pasien memelihara kebersihan gigi tiruan sebagian lepasan dapat dilihat dari frekuensi, waktu, dan cara yang digunakan untuk membersihkan gigi tiruan bervariasi pada setiap individu dan masyarakat yang berbeda. Tujuan dari penelitian ini yaitu untuk mengetahui gambaran perilaku dan cara merawat GTSL pada lansia di Panti Werda Minahasa Induk. Jenis penelitian ini yaitu penelitian deskriptif dengan pendekatan cross sectional study. Sampel adalah semua lansia yang memenuhi kriteria inklusi yaitu yang berusia 60-80 tahun, menggunakan GTSL di tujuh Panti Werda di Minahasa Induk. Berdasarkan hasil penelitian yang telah dilakukan, responden paling banyak membersihkan GTSL dengan cara menyikat tanpa pasta gigi 1 orang $(3,3 \%)$ dan menyikat gigi dengan pasta gigi berjumlah 29 responden (96,67\%). Sebanyak 13 responden $(43,3 \%)$ tidak melakukan perendaman GTSL. Responden terbanyak hanya melakukan perendaman dengan menggunakan air yaitu 17 responden 
$(56,67 \%)$, dan tidak seorangpun yang melakukan perendaman dengan menggunakan larutan zat kimia. Sebagian besar responden yaitu 13 responden $(43,3 \%)$ membersihkan GTSL sekali sehari, sebanyak 28 responden $(93,33 \%)$ tidak menemukan kesulitan dalam membersihkan GTSL, semua responden $(100 \%)$ tidak mendapatkan isntruksi setelah pemasangan, sebanyak 22 responden $(73,3 \%)$ menggunakan GTSL pada saat malam hari ketika tidur. Simpulan: Sebagian besar responden menggunakan GTSL pada saat malam hari ketika tidur. Berdasarkan cara menyikat, responden paling banyak membersihkan GTSL dengan cara menyikat memakai sikat gigi dan pasta gigi. Berdasarkan cara merawat dengan merendam, sebagian besar responden melakukan perendaman dengan menggunakan air.

Kata kunci : gigi tiruan sebagian lepasan, lansia

Gigi tiruan sebagian lepasan adalah suatu alat yang berfungsi untuk mengembalikan beberapa gigi asli yang hilang dengan dukungan utama adalah jaringan lunak di bawah plat dasar serta dukungan tambahan dari gigi asli yang masih tertinggal dan terpilih sebagai gigi penyangga. Atau restorasi prostetik ini sering juga disebut Removable Partial Denture. ${ }^{1}$

Suatu karakteristik (sifat) geligi tiruan, yaitu kemampuan menahan gaya-gaya yang cenderung mengubah hubungan antara gigi tiruan dengan jaringan lunak mulut di mana prothesa tersebut berada, baik pada saat istirahat maupun berfungsi disebut retensi (retention). Contoh gaya-gaya seperti ini, misalnya gaya gravitasi, otot kunyah, proses penguyahan, berbicara, makan lengket serta tetap cekat dan tidak berubahnya posisi geligi tiruan terhadap suatu gaya, dinamakan stabilitas (stability). ${ }^{2}$

Dalam proses pembuatan geligi tiruan sebagian lepasan, biasanya pekerjaan diawali dengan tindakan diagnosis yang merupakan suatu proses yang dilakukan untuk menetapkan adanya suatu keadaan yang tidak wajar, meneliti abnormalitas serta menentukan penyebabnya. Tahap diagnosis ini dapat dibantu dengan pencetakan rahang (jaw impression) yang akan menghasilkan cetakan rahang dalam bentuk negatif lengkung gigi dan jaringan sekitarnya yang kita cetak. ${ }^{2}$

Sebuah cetakan yang dicor dengan salah satu jenis gips akan menghasilkan reproduksi positif berupa model rahang (cast). Dengan bantuan model ini, ditambah hasil pemeriksaan klinis sebelumnya, keadaan mulut penderita dapat dipelajari tanpa kehadiran pasien sekalipun, untuk menentukan rencana perawatan selanjutnya. Karena itulah, model rahang semacam ini disebut model diagnostik (diagnostic cast atau study cast). ${ }^{2}$

Kebutuhan penggunaan gigi tiruan meningkat pada kelompok usia lanjut karena mengalami perubahan-perubahan fisiologis dalam rongga mulut mereka termasuk kehilangan gigi. Pada usia lanjut yang biasa dikenal sebagai istilah lansia merupakan tahap akhir siklus kehidupan dari perkembangan normal yang dialami dan tidak dapat dihindari oleh setiap individu, maka banyaknya jumlah pasien lansia yang tidak mempunyai gigi menyebabkan perawatan gigi diutamakan pada perawatan prostodontik.

Organisasi Kesehatan Dunia (World Health Organisation) menggolongkuan lansia menjadi 4 yaitu: usia pertengahan (middle age) adalah 45 - 59 tahun, lanjut usia (elderly) adalah $60-74$ tahun, lanjut usia tua (old) adalah 75 - 90 tahun dan usia sangat tua (very old) diatas 90 tahun. $^{2}$ Lanjut usia menurut Keliat (1999) dikatakan sebagai tahap akhir perkembangan pada daur kehidupan manusia. Sedangkan menurut Pasal 1 ayat (2), (3), (4), UU No. 13 Tahun 1998 tentang Kesehatan dikatakan bahwa usia lanjut adalah seseorang yang telah mencapai usia lebih dari 60 tahun. ${ }^{3}$

Kebiasaan pasien memelihara kebersihan gigi tiruan sebagian lepasan dapat diihat dari frekuensi, waktu, dan cara yang digunakan untuk membersihkan gigi 
tiruan bervariasi pada setiap individu dan masyarakat yang berbeda. ${ }^{7}$ Pada lansia mereka tidak memiliki kemampuan yang cukup untuk memelihara kebersihan rongga mulut dan gigi tiruan, sedangkan hal ini merupakan kunci keberhasilan perawatan gigi tiruan, baik cekat maupun lepasan. ${ }^{4}$

Memelihara kebersihan gigi tiruan sebagian lepasan dapat diterapkan melalui frekuensi, waktu, dan cara yang digunakan untuk membersihkan gigi tiruan. Setiap satu kali sehari sebelum tidur, sangat penting untuk melepas gigi tiruan dari rongga mulut dan merendamnya dalam larutan pembersih untuk membunuh mikroorganisme pada gigi tiruan dan membersihkan stein yang ada, yang diikuti menyikat dengan pasta gigi setiap selesai makan. ${ }^{5}$ Gigi tiruan dan rongga mulut harus dibersihkan setiap setelah makan. Pada malam hari, gigi tiruan harus dilepas dan direndam dalam larutan pembersih gigi tiruan. Perendaman gigi tiruan dalam larutan pembersih dapat dilakukan sepanjang malam, 2 jam, 1 jam atau 30 menit tergantung dari bahan pembersih yang digunakan. $^{4}$

Metode dan bahan pembersihan gigi tiruan dapat diklasifikasikan metode penyikatan: metode perendaman zat kimia yang terdiri dari perendaman dengan larutan enzim, larutan asam, larutan buffer Hipoklorit Alkalin, disinfektan: metode kombinasi penyikatan dan perendaman: metode pembersihan ultrasonik. ${ }^{4}$

Berdasarkan uraian di atas penulis tertarik untuk meneliti tentang gambaran perilaku dan cara merawat gigi tiruan sebagian lepasan pada lansia di panti-panti werda di Minahasa Induk.

\section{BAHAN DAN METODE PENELITIAN}

Jenis penelitian ini yaitu penelitian deskriptif dengan pendekatan cross sectional study yang bertujuan untuk mengetahui gambaran perilaku dan cara merawat gigi tiruan sebagian lepasan pada lansia di panti-panti werda Minahasa Induk.
Metode pengambilan sampel pada penelitian ini dengan total sampel, instrumen yang digunakan kuesioner dan alat tulis menulis.

Populasi penelitian ini ialah seluruh lansia di tujuh panti werda di Minahasa Induk dengan jumlah populasi 30 orang lansia yang terdiri dari Panti Sosial Tresna Werda Agape Tondano 5 orang lansia pengguna gigi tiruan, Panti Sosial INA I 2 orang lansia pengguna gigi tiruan, Panti Werda Debora 5 orang lansia pengguna gigi tiruan, Panti Sosial Tresna Werda Yakobus Peduli 7 orang lansia pengguna gigi tiruan, Panti Werda Hana 3 orang lansia pengguna gigi tiruan, Panti Sosial Tresna Werda Tabita 2 orang lansia pengguna gigi tiruan, dan Panti Werda Pengasih 6 orang lansia pengguna gigi tiruan. Sampel penelitian yaitu semua lansia yang menggunakan gigi tiruan sebagian lepasan, dengan kriteria Inklusi Lansia usia 60-80 tahun yang menggunakan GTSL, bersedia menjadi sampel penelitian dan mengisi kuisioner. Kriteria ekslusi Pasien lansia yang sudah tidak mampu untuk diajak komunikasi dengan efektif.

Data yang telah dikumpulkan kemudian dianalisa dengan analisis univariat menggunakan program Microsoft Excel dan disajikan dalam bentuk tabel.

\section{HASIL PENELITIAN}

Jumlah responden yang diwawancarai adalah 30 orang dengan kriteria inklusi kehilangan sebagian gigi di rahang atas dan rahang bawah, atau di rahang atas dan rahang bawah yang memakai gigi tiruan sebagian lepasan. Responden sebanyak 30 orang didapatkan dari 7 panti werda yang berada di Kabupaten Minahasa Induk.

Dari hasil penelitian diperoleh jumlah responden terbanyak yaitu usia lansia 75-90 tahun berjumlah 17 responden $(56,67 \%)$, dan responden dengan jumlah terkecil usia remaja 60-74 tahun yaitu 13 responden $(43,3 \%)$. Jumlah responden yang memakai GTSL berjenis kelamin perempuan lebih 
banyak dibandingkan laki-laki yaitu 28 orang $(93,3 \%)$. Berdasarkan pendidikan jumlah responden terbanyak yaitu responden yang tamat SMA/setara dan SD sebanyak 10 responden $(43,3 \%)$, dan responden dengan jumlah terkecil pendidikan SD sebanyak 7 responden $(8 \%)$.

\section{Gambaran hasil Penilaian dari kuesioner}

Tabel 1. Distribusi pasien berdasarkan penggunaan GTSL

\begin{tabular}{cccc} 
No & $\begin{array}{c}\text { Lama penggunaan } \\
\text { GTSL (tahun) }\end{array}$ & $\mathrm{n}$ & $\%$ \\
\hline 1 & $<1$ & 2 & 6,67 \\
2 & $1-5$ & 13 & 43,3 \\
3 & $6-10$ & 10 & 33,3 \\
4 & $10>$ & 5 & 16,67 \\
\hline & Total & 30 & 100 \\
\hline
\end{tabular}

Tabel 2. Distribusi responden berdasarkan metode pembersihan secara mekanik

\begin{tabular}{cccc}
\hline No & $\begin{array}{c}\text { Metode } \\
\text { Pembersihan } \\
\text { GTSL }\end{array}$ & N & $\%$ \\
\hline 1 & Air+sikat & 1 & 3,3 \\
2 & Air, sabun, sikat & 29 & 96,67 \\
\hline & Total & 30 & 100 \\
\hline
\end{tabular}

Tabel 3. Distribusi responden berdasarkan metode pembersihan secara kimiawi

\begin{tabular}{cccc}
\hline No. & $\begin{array}{c}\text { Kebiasaan } \\
\text { merendam GTSL }\end{array}$ & $\mathrm{N}$ & $\%$ \\
\hline 1 & Tidak direndam & 13 & 43,3 \\
2 & $\begin{array}{c}\text { Direndam air } \\
\text { Direndam } \\
\text { menggunakan }\end{array}$ & 17 & 56,67 \\
3 & 0 & 0 \\
& $\begin{array}{c}\text { arutan zat kimia } \\
\text { dan air }\end{array}$ & & \\
\hline & Total & 30 & 100 \\
\hline
\end{tabular}

Tabel 4. Distribusi pasien berdasarkan frekuensi pembersihan

\begin{tabular}{cccc}
\hline No & $\begin{array}{c}\text { Frekuensi } \\
\text { pembersihan GTSL } \\
\text { per hari }\end{array}$ & N & $\%$ \\
\hline 1 & $<1$ & 2 & 6,67 \\
2 & 1 & 13 & 43,3 \\
3 & 2 & 10 & 33,3 \\
4 & 3 & 5 & 16,67 \\
5 & $>3$ & 0 & 0 \\
\hline & Total & 30 & 100 \\
\hline
\end{tabular}

Tabel 5. Distribusi pasien berdasarkan kesulitan pembersihan GTSL

\begin{tabular}{cccc}
\hline No & $\begin{array}{c}\text { kesulitan } \\
\text { pembersihan GTSL }\end{array}$ & $\mathrm{n}$ & $\%$ \\
\hline 1 & Ya & 2 & 6,67 \\
2 & Tidak & 28 & 93,33 \\
& Total & 30 & 100 \\
\hline
\end{tabular}

Tabel 6. Distribusi pasien berdasarkan penerimaan instruksi

\begin{tabular}{cccc}
\hline No & $\begin{array}{c}\text { Menerima } \\
\text { Instruksi }\end{array}$ & $\mathrm{N}$ & $\%$ \\
\hline 1 & Ya & 2 & 6,67 \\
2 & Tidak & 28 & 93,33 \\
\hline & Total & 30 & 100 \\
\hline
\end{tabular}




\section{BAHASAN}

Berdasarkan hasil penelitian, responden terbanyak memakai GTSL di rahang atas saja dan rahang bawah saja, dan pada kedua rahang masing-masing selama 1-5 tahun yaitu berjumlah 13 responden $(43,3 \%)$. Hasil ini sesuai dengan penelitian Ina Patel yang menunjukan bahwa responden terbanyak menggunakan GTSL adalah 1-5 tahun. ${ }^{6} \mathrm{Hal}$ ini disebabkan kualitas gigi tirusan yang cukup baik sehingga gigi tiruan

Tabel 7. Distribusi pasien berdasarkan kebiasaan penggunaan GTSL pada malam hari (saat tidur)

\begin{tabular}{cccc}
\hline No & $\begin{array}{c}\text { Penggunaan GTSL } \\
\text { pada malam hari }\end{array}$ & $\mathrm{N}$ & $\%$ \\
\hline 1 & $\begin{array}{c}\text { Melepas GTSL } \\
\text { Tidak melepas } \\
\text { GTSL }\end{array}$ & 8 & 26,67 \\
2 & Total & 30 & 100 \\
\hline
\end{tabular}

Responden yang membersihkan GTSL dengan cara menyikat tanpa pasta gigi 1 orang $(3,3 \%)$ dan menyikat gigi dengan pasta gigi berjumlah 29 responden (96,67\%). Hasil ini sejalan dengan penelitian yang dilakukan oleh Sipayung yang menunjukan bahwa teknik paling umum yang digunakan responden dalam membersihkan GTSL ialah dengan menyikat menggunakan pasta gigi. ${ }^{6}$

Metode membersihkan GTSL dengan menggunakan sikat gigi, dianjurkan untuk dilakukan secara teratur. Namun, hal ini juga dapat menyebabkan abrasi permukaan yang dapat merusak unsur estetik dan biologis.

GTSL. Kandungan bahan kimia yang terkandung dalam pasta gigi juga dapat merusak bahan GTSL sehingga akan menyebabkan permukaan GTSL menjadi kasar. Permukaan yang kasar dapat meningkatkan akumulasi plak pada GTSL. Oleh karena itu menyikat GSTL menggunakan pasta gigi perlu didukung dengan teknik yang tepat. ${ }^{8}$ Selain itu, membersihkan GTSL dengan menyikat yang dipakai dapat bertahan dalam waktu yang cukup lama meskipun dengan pemeliharaan kebersihan yang kurang tepat. Menurut Lombardi dan Budtz-Jorgensen, GTSL yang sudah lama dapat mempengaruhi pasien untuk menjadi denture stomatitis, karena permukaan gigi tiruan bersifat porositas yang membuat pembersihan yang tepat sulit dilakukan. ${ }^{7}$

dengan atau tanpa pasta gigi tidak akan cukup karena tidak cukup untuk membunuh mikro-organisme. Metode pembersihan secara mekanis perlu didukung dengan metode pembersihan secara kimiawi yaitu dengan dilakukan perendaman menggunakan larutan perendaman GTSL. ${ }^{9}$

Berdasarkan hasil penelitian, sebanyak 13 responden $(43,3 \%)$ tidak melakukan perendaman GTSL. Responden terbanyak hanya melakukan perendaman dengan menggunakan air yaitu 17 responden $(56,67 \%)$, dan tidak seorangpun yang meakukan perendaman dengan menggunakan larutan zat kimia. Pada penelitian ini tidak seorangpun yang melakukan perendaan dengan larutan zat kimia disebabkan sebagian besar responden memiliki pendidikan yang rendah dan semua responden melakukan pemasangan GTSL pada tukang gigi sehingga tidak mendapatkan instruksi cara merawat GTSL yang baik dan benar. Hal ini sejalan dengan penelitian yang dilakukan oleh Patel yang menunjukan bahwa responden lebih banyak 
melakukan perendaman dengan air dibandingan larutan zat kimia atau larutan disinfektan. ${ }^{10}$

Metode perendaman kimia memiliki keuntungan yaitu mudah digunakan sebagai bahan pembersih. Namun, metode pembersihan secara kimia memiliki kelemahan karena biaya yang tinggi dan menyebabkan logam dan akrilik mudah korosi sehingga dapat mengakibatkan kerusakan pada basis gigi tiruan. Larutan zat kimia atau disinfektan juga dapat menjadi alternative penting, terutama untuk pasien usia lanjut yang kemampuan motoriknya mulai berkurang. ${ }^{11}$ Idealnya, kedua mekanisme harus digunakan bersama-sama untuk mencapai kontrol plak yang lebih baik. Kombinasi menyikat dan metode perendaman telah direkomendasikan sebagai cara yang efektif untuk membersihkan GTSL oleh para dokter gigi. ${ }^{12}$

Sebagian besar responden yaitu 13 responden $(43,3 \%)$ membersihkan GTSL sekali sehari. Hasil ini serupa dengan penelitian yang dilakukan oleh Dikbas dkk yang menunjukan bahwa kabanyakan responden yaitu 164 responden $(70 \%)$ hanya membersihkan ${ }^{6}$ GTSL sekali dalam sehari. Hal ini kemungkinan dikarenakan responden yang usianya berada di atas 60 tahun, mulai kehilangan kemampuan motorik untuk melakukan pembersihan secara mekanik.

Kebiasaan memelihara kebersihan gigi tiruan yang terdiri dari frekuensi, waktu, dan cara pembersihan memiliki keterkaitan sangat erat diantara ketiganya untuk mengindikasikan pemeliharaan kebersihan yang baik dan benar. Apabila dilihat antara frekuensi dan waktu pembersihan, responden yang membersihkan GTSL dengan frekuensi yang lebih sering dan teratur setiap hari belum tentu baik jika waktu responden membersihkan GTSL tidak tepat, dimana responden tersebut harus membersihkan gigi tiruannya setiap setelah makan. Waktu pembersihan yang tepat lebih mengindikasikan kebiasaan memelihara kebersihan gigi tiruan yang baik dan benar dibandingkan frekuensi pembersihan. Responden yang membersihkan GTSL dengan frekuensi dan waktu pembersihan yang tepat juga belum mengindikasikan pemeliharaan kebersihan yang baik, jika cara pembersihan yang dilakukan tidak tepat. Kebiasaan memelihara kebersihan gigi tiruan yang baik dan benar dapat dicapai melalui frekuensi, waktu, dan cara pembersihan yang tepat. ${ }^{13}$

Sebagian besar responden tidak menemukan kesulitan dalam membersihkan GTSL. Hasil penelitian ini sejalan dengan penelitian yang dilakukan oleh Patel yang mununjukan bahwa sebagian besar responden tidak menemukan kesulitan membersihkan GTSL. ${ }^{10}$ Pada responden yang mengalami kesulitan membersihkan dalam penelitian ini adalah responden berusia diatas 80 tahun, dimana pada usia ini kemampuan motorik sudah jauh menurun. Hasil penelitian Nevalainen menunjukan bahwa usia 80 tahun atau lebih, tidak efisien dalam membersihkan GTSL karena keterbatasan seperti pengurangan ketajaman visual dan ketangkasan manual.

Berdasarkan hasil penelitian semua 30 responden $(100 \%)$ tidak mendapatkan instruksi setelah pemasangan. Hasil ini berbeda dengan hasil penelitian yang dilakukan oleh Patel yang menunjukan bahwa sebagian besar responden mendapatkan instruksi cara merawat GTSL setelah pemasangan ${ }^{10}$. Hal ini dikarenakan responden pada penelitian ini semuanya menggunakan GTSL yang dibuat oleh tukang gigi sehingga tidak mendapatkan perhatian terhadap pentingnya pemberian instruksi secara lisan dan tulisan tentang cara yang tepat memelihara kebersihan gigi tiruan untuk keberhasilan perawatan jangka panjang.

Studi sebelumnya telah melaporkan bahwa sebagian besar pemakai gigi tiruan tidak tahu bagaimana untuk membersihkan gigi tiruan karena tidak pernah menerima instruksi dari doker gigi mereka. Untuk menginstruksikan pemakai GTSL tentang 
kebersihan yang layak merupakan salah satu tanggung jawab dokter gigi. Namun, telah diamati bahwa mayoritas pemakai gigi tiruan tidak memperhatikan kebersihan GTSL. Hal ini mungkin karena kelalaian pemakai gigi tiruan serta dokter gigi yang tidak memberikan cukup instruksi kepada pasien mereka tentang metode pembersihan gigi tiruan. Dalam penelitian ini juga telah menyatakan bahwa meskipun pasien mendapatkan petunjuk yang benar dari dokter gigi mereka mungkin tidak mengikuti instruksi tersebut. ${ }^{8}$

Responden yang menggunakan GTSL pada saat malam hari ketika tidur sebanyak 22 orang $(73,3 \%)$. Hasil penelitian ini sejalan dengan hasil penelitian yang dilakukan oleh De Castellucci Barbosa yang menunjukan bahwa 64\% responden tetap menggunakan GTSL dimalam hari ketika tidur. ${ }^{5}$ Hal ini kemungkinan disebabkan oleh kurangnya informasi yang diperoleh responden tentang penggunaan serta perawatan GTSL yang baik.

\section{SIMPULAN}

Berdasarkan hasil penelitian yang telah dilakukan, dapat disimpulkan bahwa:

1. Berdasarkan perilaku, sebagian besar responden menggunakan GTSL pada saat malam hari ketika tidur.

2. Berdasarkan cara menyikat, responden paling banyak membersihkan GTSL dengan cara menyikat memakai sikat gigi dan pasta gigi.

3. Berdasarkan cara merawat dengan merendam, sebagian besar responden melakukan perendaman dengan menggunakan air.

\section{SARAN}

1. Bagi peneliti perlu dilakukan penelitian lebih lanjut untuk meneliti kebiasaan memelihara kebersihan gigi tiruan berdasarkan pekerjaan, ras, lingkungan tempat tinggal, lingkungan sosial, dan kesehatan sosial, dan kesehatan sistemik responden.
2. Bagi masyarakat khususnya lansia perlu mempebaiki perilaku dan cara merawat gigi tiruan sebagian lepasan yaitu tentang frekuensi, waktu, dan cara memelihara kebersihan gigi tiruan yang benar.

3. Bagi pemerintah daerah Minahasa Induk khususnya Dinas Kesehatan, diharapkan dapat meningkatkan kinerja dalam pemberian pelayanan dibidang prostodonsi dan memberikan edukasi tentang pentingnya menjaga kesehatan gigi dan mulut pada pengguna gigi tiruan

\section{DAFTAR PUSTAKA}

1. Applegate, 1960, Essentials of Removable Partial Denture Prothesis, 2nd edition, W.B. Saunders Co. Philadelphia

2. Sumber:(http://www.drsimonrosenberg.com/ Removable-Partial Denture.html)

3. Maryam S, Ekasari M F, Rosidawati, Ahmad J, Irwan B. mengenal usia lanjut dan perawatannya. Jakarta: Salemba Medika;2008: p.31-32

4. Barreiro D M, Scheid P A, May L G, Unfer B, Braun K O. Evaluation of Proderes Employed for the Maintenance of Removable Dentures in Eldery Individuals. Oral Health prev Dent J 2009;7:243-249

5. Barbosa D.B, Souza R F d, Pero A C, Marra J, Compagnoni M A. Flexural strength of acrylic resins polymerized by different Cycles. J Appl Oral Sci 2007;15(5);424-8.

6. Sipayung BI. Kebiasaan memelihara kebersihan gigitiruan pada masyarakat pemakai gigitiruan sebagian lepasan di kelurahan tanjung rejo kecamatan medan sunggal tahun 2012. Medan: USU. 2012. hal 46-59.

7. Lombardi T, Budtz-Jorgensen E. Treatment of denture-induced stomatitis: areview. Eur J Prosthodont Restor Dent 1993;2:17.

8. Dikbas I, Koskal T, Calikkocaoglu S. investigation of the cleanliness of dentures in a Unniversity Hospital. The International Journal of prostodontich; 2006;16(3):294-298 
9. Barnabe' W. Efficacy of sodium hypochlorite and coconut soap used as disinfecting agents in the reduction of denture stomatitis, Streptococcus mutans and Candida albicans. J Oral Rehabil 2004;31:453-9.

10. Patel, I.B, Gauri Madan G, Pat el B, Solanki K, Chavda R. Habits of a sample population of complete denture wearers in Ahmedabad. J. Int Oral Health may-ags 2012; 4(2):29-38
11. Jagger DC, Harrison A. Denture cleansing - the best approach. $\mathrm{Br}$ Dent J 1995;178:413-7.

12. Jegenathan S, Payne JA, Theam HPY. Denture stomatitis in an elderly edentulous Asian population. J Oral Rehabil 1997;24:468-72.

13. Chittaranjan B, Taruna, Sudhir, Bharath. Material and Methods for cleaning the Dentures. IJDA January-March2011; 3(1), p. 423-426 